\title{
EFFECT OF DIFFERENT AMOUNT OF WATER HYACINTH AS MULCH ON POTATO AND TOMATO AT THE SALINE SOIL OF NOAKHALI
}

\author{
S. K. BHOWMIK'1, S. K. BHOWAL ${ }^{2 *}$, M. M. CHOWDHURY³, M. A. RAHMAN4,
}

A. H. M. A. FAISAL ${ }^{5}$, I. S. M. FARHAD ${ }^{6}$

\author{
${ }^{1}$ Agriculture Extension Officer, Department of Agricultural Extension, Nabinagar, \\ Brahmanbaria, Bangladesh \\ ${ }^{2 *}$ Scientific Officer, On- Farm Research Division, Bangladesh Agricultural Research Institute, \\ Cumilla, Bangladesh \\ ${ }^{3}$ Principal Scientific Officer, On- Farm Research Division, Bangladesh Agricultural Research Institute, \\ Noakhali, Bangladesh \\ ${ }^{4}$ Senior Scientific Officer, On- Farm Research Division, Bangladesh Agricultural Research Institute, \\ Tangail, Bangladesh \\ ${ }^{5}$ Scientific Officer, On- Farm Research Division, Bangladesh Agricultural Research Institute, \\ Noakhali, Bangladesh \\ ${ }^{6}$ Scientific Officer, Soil Science Division, Bangladesh Agricultural Research Institute, \\ Gazipur, Bangladesh \\ *(shamal.bau@gmail.com)
}

This journal is licensed under a Creative Commons Attribution-NonCommercial 4.0 International License (CC-BY-NC). Articles can be read and shared for noncommercial purposes under the following conditions:

- BY: Attribution must be given to the original source (Attribution)

- NC: Works may not be used for commercial purposes (Noncommercial)

This license lets others remix, tweak, and build upon your work non-commercially, and although their new works must also acknowledge you and be non-commercial, they don't have to license their derivative works on the same terms. License Deed Link: http://creativecommons.org/licenses/by-nc/4.0/

Legal Code Link: http://creativecommons.org/licenses/by-nc/4.0/legalcode

$A B C$ Research Alert uses the CC BY-NC to protect the author's work from misuse.

\section{Abstract}

The experiment was conducted at the farmer's field of FSRD site, Hazirhat, Noakhali, during the Rabi season (2014-15 \& 2015-16) to observe the effect of different amount of water hyacinth as mulch on potato and tomato at the saline soil of Noakhali. Different mulch treatments viz. $T_{1}=$ No mulch, $T_{2}=56 \mathrm{t} / \mathrm{ha}, \mathrm{T}_{3}=62 \mathrm{t} / \mathrm{ha}$ and $\mathrm{T}_{4}=68 \mathrm{t} / \mathrm{ha}$ were tested in the experiment. Different amount of water hyacinth had marked effect on soil moisture conservation to reduce the adverse effect of soil salinity. The maximum soil moisture (\%) status and the lowest salinity level ( $\left.\mathrm{dS} \mathrm{m}^{-1}\right)$ recorded both for potato and tomato at harvest stage mulched with $68 \mathrm{t}$ water hyacinth ha-1. The highest yield $26.46 \mathrm{t} \mathrm{ha}^{-1}$ and $67.29 \mathrm{t} \mathrm{ha}^{-1}$ coupled with gross margin $165800 \mathrm{tk}^{\mathrm{h}} \mathrm{ha}^{-1}$ and $646930 \mathrm{tk}^{-1} \mathrm{ha}^{-1}$ obtained from $T_{4}$ treatment both for potato and tomato, respectively. Cultivation of Potato and Tomato with water hyacinth as mulch @ $68 \mathrm{t} \mathrm{ha}^{-1}$ might be a good option to minimize the adverse effect of soil salinity as well as for higher yield and economic return at the saline soil of Noakhali. Keywords

Mulching, Tomato, Potato, Soil salinity, Yield

\section{INTRODUCTION}

Potato and Tomato are the most important vegetables grown in Bangladesh. Potato (Solanum tuberosum) is the best vegetable crop of Bangladesh both in terms of area and production that can meet up vegetable demand and provide necessary nutrients for the people of low income group (Islam et al., 
2009). Its cultivation area is 4.62 lakh ha and production 89.50 lakh tons in Bangladesh whereas in Noakhali, the production area is only 184.0 ha (BBS, 2014). Tomato (Lycopersicon esculentum Mil.) is another important vegetable that contributes significantly to the nutrition of people as a source of vitamins and minerals. Both of these crops grown during winter season (except summer tomato) when the rainfall is scanty. The production of potato and tomato specially potato is constrained in the coastal area of Noakhali caused by lack of irrigation facilities due to surface water scarcity and ground water salinity during the dry season viz, November-May (Karim et al., 1990).

Soil moisture and soil salinity has a reciprocal relation. The more moisture in soils represents the less salinity in soil. Mulch has been found the most effective management means to reduce dry season salinity by conserving moisture in the root zone (Chi et al., 1994). This practice also encourages deeper and denser rooting by minimizing evaporation losses (Allamanas et al., 1977; Choudhury and Prihar, 1974).

Rice husk, saw dust, leaf mould and water hyacinth can be used as mulch materials. Among them water hyacinth (Eichornia crassipes) is considered as the best mulching materials in this region as it is grown profusely in abundant stagnant water bodies and it can retain moisture in the soil for longer period (Razzaque and Ali, 2009). The use of water hyacinth as mulch in potato and tomato has been in practice but little information regarding effect of different amount of water hyacinth as mulch on potato and tomato at the saline soil of Noakhali is available in Bangladesh. Hence, an investigation was undertaken to evaluate the effect of different amount of water hyacinth as mulch on potato and tomato.

\section{MATERIALS AND METHODS}

The experiment was conducted at FSRD site, Hazirhat, Noakhali during Rabi season (2014-2015). Important meteorological parameters i.e. mean monthly maximum and minimum temperature $\left({ }^{\circ} \mathrm{C}\right)$ and monthly rainfall $(\mathrm{mm})$ of the growing season were recorded (Graph. 01).

The soil was silty clay loam belonging to Hatia series of Young Meghna Estuarine Flood plain of Bangladesh. The experiment was laid out in Randomized Complete Block design with six dispersed

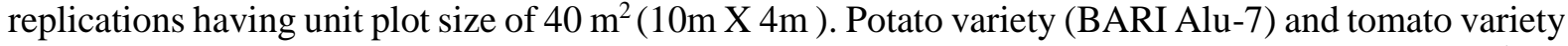
(BARI Tomato-14) used in this study. Different mulch treatments viz. $\mathrm{T}_{1}=$ No mulch, $\mathrm{T}_{2}=56 \mathrm{t} \mathrm{ha}^{-1}, \mathrm{~T}_{3}$ $=62 \mathrm{t} \mathrm{ha}^{-1}$ and $\mathrm{T}_{4}=68 \mathrm{t} \mathrm{ha}^{-1}$ were tested in the experiment. Water hyacinth was collected from nearby water bodies and kept in a heap for 7 days before placing on the plot.

Incase of potato, tubers were planted @ $1.5 \mathrm{t} / \mathrm{ha}$ maintaining spacing $60 \mathrm{~cm} \mathrm{X} 25 \mathrm{~cm}$ on 2 to 3 December in two consécutive years. After that, plots were covered by water hyacinth according to the treatments. Plots were fertilized with 115-30-125-27 kg ha ${ }^{-1}$ of N-P-K-S, respectively. All fertilizers were applied during final land preparation. Fungicide Cuprofix 30 disperss was sprayed @ 2.0g L $\mathrm{g}^{-1}$ of water at 7 days interval when blight disease affected the crop at tuber formation stage. The potato was harvested on 8 to 10 March in both the years.

In case of tomato, 25 to 27 days old seedlings were transplanted on 2 to 3 December maintaining spacing $60 \mathrm{~cm} \mathrm{X} 40 \mathrm{~cm}$. Plots were fertilized with $207-50-125 \mathrm{~kg} \mathrm{ha}^{-1}$ of N-P-K, respectively. Full amount of TSP and half of MoP were applied during final land preparation. The entire amount of urea and remaining MoP were applied in 2 equal installments at 15 and 30 days after transplanting. After fertilization, mulch was applied in experimental plots according to the treatments. Plant protection measure and all other management practices were done as and when necessary.

The harvesting of Tomato was starts 25 February and continues up to 10 April. Data on the different crop parameters were collected from the 10 sample plants and then average was taken which was further analyzed by computer program MSTAT-C. Soil moisture regimes of the experimental plots were recorded at a depth of $0-15 \mathrm{~cm}$ at 15 days interval by using gravimetric method. Soil salinity level was measured by using Electrical Conductivity meter Adwa (AD 310) at 7 days interval and presented as different growth stage wise of potato and tomato in Table (3) and Table (4) respectively. 


\section{RESULTS AND DISCUSSION}

\subsection{Changes of soil moisture as influenced by different amount of mulch}

Soil moisture status of experimental plot varied among the treatments in different growth stages of potato (Fig. 1) and tomato (Fig. 2). Soil moisture in plot mulched with $68 \mathrm{t}$ water hyacinth $\mathrm{ha}^{-1}\left(\mathrm{~T}_{4}\right)$ decreased at slower rates followed by $\mathrm{T}_{3}$ and $\mathrm{T}_{2}$ mulched with $62 \mathrm{t}$ and $56 \mathrm{t} \mathrm{ha}^{-1}$, respectively. On the other hand, soil moisture decreased at higher rate in $\mathrm{T}_{1}$ treatment. This result revealed that increased amount of water hyacinth as mulch helps to conserve more moisture in soil over control.

\subsection{Effect of different amount of water hyacinth as mulch on soil salinity of potato field}

Soil salinity level gradually increased from planting to maturity stage of the crop (Table 1). Initial salinity level was more or less same among the treatments. Salinity level increased at slower rate in $\mathrm{T}_{4}$ treatment followed by $\mathrm{T}_{3}$ and $\mathrm{T}_{2}$. On the other hand, salinity level increased at higher rate in $\mathrm{T}_{1}$ treatment. This variation occurred among the treatments might be due to more moisture conservation in $\mathrm{T}_{4}$ followed by $\mathrm{T}_{3}, \mathrm{~T}_{2}$ and $\mathrm{T}_{1}$.

The maximum salinity level $\left(7.22-8.45 \mathrm{dS} \mathrm{m}^{-1}\right)$ recorded from $\mathrm{T}_{1}$ (No mulch) treatment whereas, the minimum salinity level (3.62-4.35 $\left.\mathrm{dS} \mathrm{m}^{-1}\right)$ recorded from $\mathrm{T}_{4}$ treatment at harvest stage. The findings was at par with Rahaman et al. (2004) who reported that potato could be cultivated in saline soil by minimizing salinity with application of mulch.

\subsection{Effect of different amount of water hyacinth as mulch on soil salinity of tomato field}

Soil salinity level gradually increased from planting to maturity stage of the crop (Table 2). Initial salinity level was more or less same among the treatments. Salinity level increased at slower rate in $\mathrm{T}_{4}$ treatment followed by $\mathrm{T}_{3}$ and $\mathrm{T}_{2}$. On the other hand, salinity level increased at higher rate in $\mathrm{T}_{1}$ treatment. This variation occurred among the treatments might be due to more moisture conservation in $\mathrm{T}_{4}$ followed by $\mathrm{T}_{3}, \mathrm{~T}_{2}$ and $\mathrm{T}_{1}$. The maximum salinity level $\left(7.22-8.45 \mathrm{dS} \mathrm{m} \mathrm{m}^{-1}\right.$ ) recorded from $\mathrm{T}_{1}$ (No mulch) treatment whereas, the minimum salinity level $\left(3.62-4.35 \mathrm{dS} \mathrm{m}^{-1}\right)$ recorded from $\mathrm{T}_{4}$ treatment at harvest stage.

\subsection{Effect of different amount of water hyacinth as mulch on the yield and yield contributing characters of Potato}

The result indicated that studied plant characters of potato were significantly influenced by different treatments except stem number hill ${ }^{-1}$ presented in Table (3). Different amount of mulch had significant influence on plant height. The highest plant height $(45.67 \mathrm{~cm})$ obtained from $\mathrm{T}_{4}$ which was statistically at par with $\mathrm{T}_{3}$ and $\mathrm{T}_{2}$. The lowest plant height $(34.10 \mathrm{~cm})$ obtained from no mulch condition.

The maximum number of tuber hill-1 ${ }^{-1}(7.87)$ was recorded from $T_{4}$ treatment that followed by $T_{3}$ and $T_{2}$ treatment. In contrast the lowest number of tuber hill ${ }^{-1}$ (5.86) recorded from $\mathrm{T}_{1}$ treatment. Significant variation in tuber wt. hill ${ }^{-1}$ was observed from different treatments. Treatment $\mathrm{T}_{4}$ gave maximum tuber wt. hill ${ }^{-1}(406.1 \mathrm{~g})$ followed by $\mathrm{T}_{3}(369.7 \mathrm{~g})$ and $\mathrm{T}_{2}(327.3 \mathrm{~g})$ whereas lowest tuber wt. hill ${ }^{-1}(259.4 \mathrm{~g})$ obtained from $\mathrm{T}_{1}$ treatment. Yield of potato significantly increased in mulched treatments over control. Similar finding was observed by (Jalil et al., 2004) where he found mulching with water hyacinth gave the highest yield and the lowest from no mulch condition.

The highest yield $\left(26.46 \mathrm{tha}^{-1}\right)$ was recorded in $\mathrm{T}_{4}$ treatment which was statistically identical with the yield obtained from $\mathrm{T}_{3}$ treatment. The lowest tuber yield $\left(26.46 \mathrm{t} \mathrm{ha}^{-1}\right)$ was recorded from $\mathrm{T}_{1}$. The decrease of tuber yield in $\mathrm{T}_{1}$ might be due to higher soil salinity in the experimental plot compared to other treatment. Higher soil salinity might be cause of lesser nutrient uptake by the plant. Plants in 
salt-affected soils often have the same appearance as plants growing under moisture stress (FAO, 2001). S.K. Rautaray, (2010) also stated that mulching is beneficial technology for rainfed potato or tomato cultivation and it improved the total tuber yield of potato by 18 to $29 \%$ in normal years.

\subsection{Effect of different amount of water hyacinth as mulch on the yield and yield contributing characters of Tomato}

The effect of different amount of mulch on morphological, yield and yield contributing characters of tomato are presented in Table (4). Plant height did not vary significantly but the tallest plant (109.41 $\mathrm{cm}$ ) obtained from $\mathrm{T}_{4}$ treatment while the shortest plant $(103.68 \mathrm{~cm})$ obtained from no mulch condition.

The number of fruits plant ${ }^{-1}$ significantly increased in mulched treatments over control. The highest number of fruits plant ${ }^{-1}(28.15)$ obtained from $\mathrm{T}_{4}$ which was statistically at par with $\mathrm{T}_{3}$ treatment. In contrast, the lowest number of fruits plant ${ }^{-1}(21.10)$ was obtained from $T_{1}$ treatment. Similar result was observed by (Kayum et al., 2008) where he found maximum number of fruits plant ${ }^{-1}(24.11)$ mulched with water hyacinth and the lowest number of fruits plant $^{-1}(20.69)$ from control.

Individual fruit wt. did not vary significantly among the treatments. Regarding yield, the highest tomato yield $\left(67.29 \mathrm{t} \mathrm{ha}^{-1}\right)$ was obtained from $\mathrm{T}_{4}$ treatment which was statistically identical with yield obtained from $\mathrm{T}_{3}$ treatment. The lowest yield $\left(55.13 \mathrm{t} \mathrm{ha}^{-1}\right)$ was recorded from $\mathrm{T}_{1}$. The lowest yield in no mulch condition might be due to higher salinity in the experimental plot compared to other treatment at the later stage of tomato. Similar results were obtained by Anonymous (2001).

\subsection{Cost and return analysis}

Cost and return analysis of potato as influenced by different treatments is presented in Table (5). From the economic point of view, gross return as well as gross margin was found higher in mulched condition over control (no mulch). The maximum gross return (264600 Tk. ha ${ }^{-1}$ ) coupled with gross margin (165800 Tk. ha ${ }^{-1}$ ) was offered by $\mathrm{T}_{4}$ treatment that was followed by $\mathrm{T}_{3}$ and $\mathrm{T}_{2}$ whereas, the minimum gross return (185800 Tk. ha $\left.{ }^{-1}\right)$ coupled with gross margin $\left(100100 \mathrm{Tk}\right.$. ha ${ }^{-1}$ ) was obtained from $\mathrm{T}_{1}$ treatment. This variation occurred due to variation of tuber yield in different treatments.

Cost and return analysis of tomato as influenced by different treatments is presented in Table (6). From the economic point of view, gross return as well as gross margin was found higher in mulched condition over control (no mulch). The highest gross return (807480 Tk. ha ${ }^{-1}$ ) and gross margin (646930Tk. ha-1) was obtained from $\mathrm{T}_{4}$ treatment that was followed by $\mathrm{T}_{3}$ and $\mathrm{T}_{2}$ whereas, the lowest gross return $(661560$ Tk. ha $\left.{ }^{-1}\right)$ and gross margin (522810 Tk. ha $\left.{ }^{-1}\right)$ was obtained from $\mathrm{T}_{1}$ treatment. This variation occurred due to variation of tomato yield in different treatments.

\section{FARMER'S OPINION}

Farmers are impressed to see the performance of BARI Alu 7 and BARI Tomato 14 grown under mulched condition $\left(68 \mathrm{t} \mathrm{ha}^{-1}\right)$ as it offers maximum gross margin which is $65.63 \%$ and $22.74 \%$ higher over control (no mulch) for potato and tomato respectively.

\section{CONCLUSION}

Cultivation of Potato and Tomato with water hyacinth as mulch @ $68 \mathrm{t} \mathrm{ha}^{-1}$ might be a good option to minimize the adverse effect of soil salinity as well as for higher yield and economic return at the saline soil of Noakhali. 


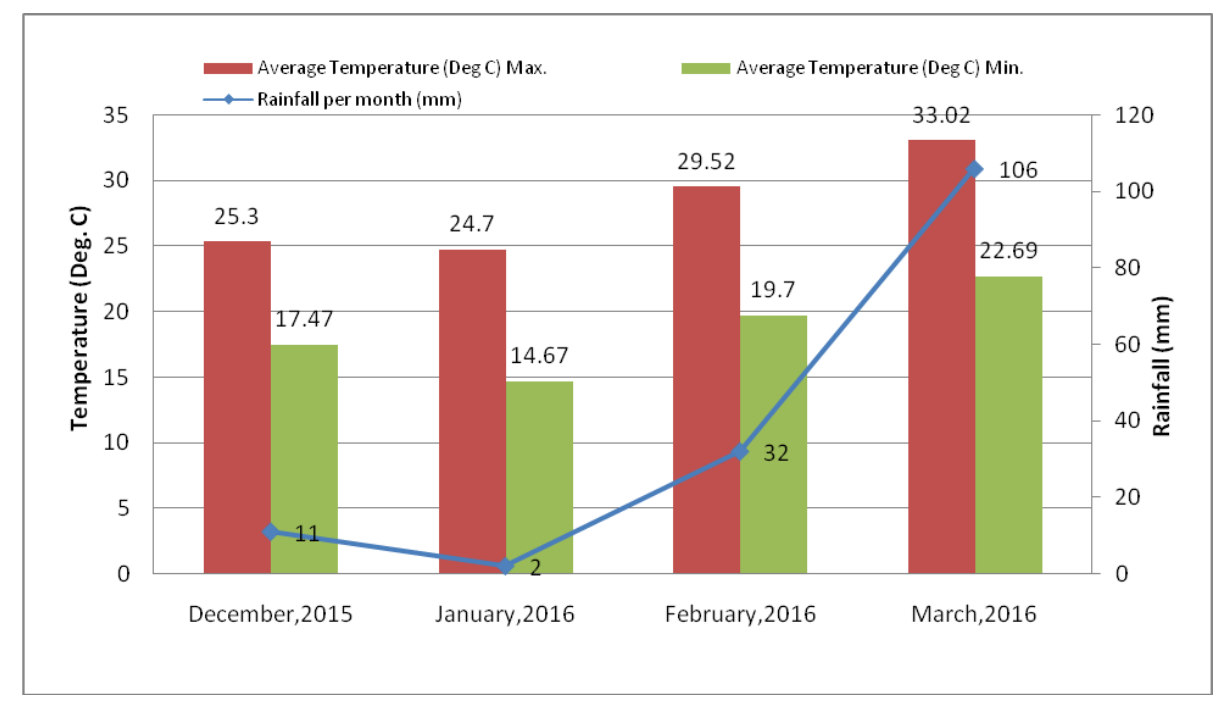

Graph 1. Rainfall level and average temperature during field trial in 2015-2016

(Source: Bangladesh Meteorological Division, Noakhali, 2016)

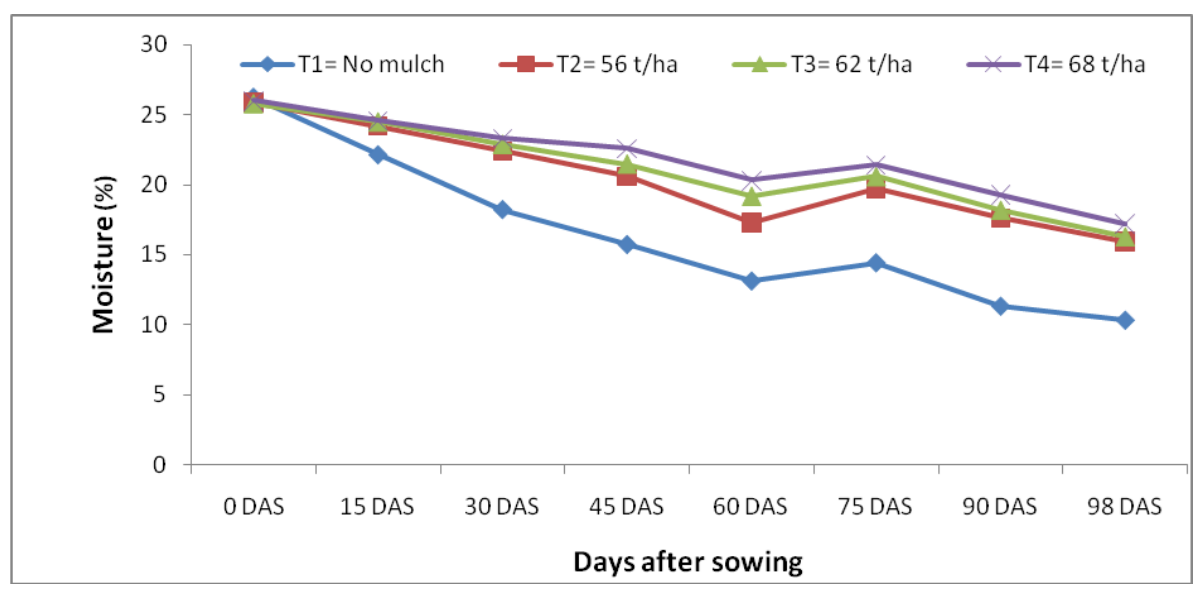

Fig. 1 Soil moisture (\%) status of potato field as influenced by various treatments at different days after sowing at FSRD site Hazirhat, Noakhali

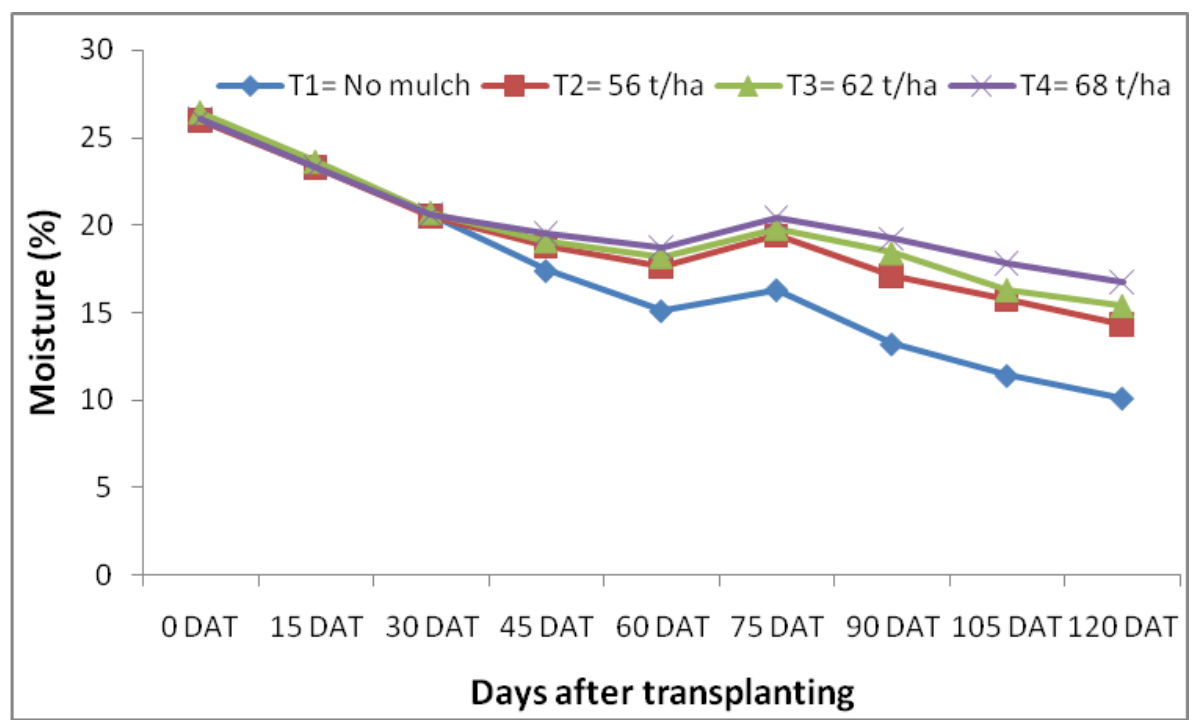

Fig. 2 Soil moisture (\%) status of tomato field as influenced by various treatments at different days after transplanting at FSRD site Hazirhat, Noakhali 


\begin{tabular}{|l|l|l|l|l|l|l|}
\hline \multirow{2}{*}{ Treatment } & \multicolumn{7}{|c|}{ Salinity range (dS m- ${ }^{\mathbf{1}}$ ) } \\
\cline { 2 - 7 } & Planting & Sprouting & Stolonization & Tuberization & Haulm Puling & Harvest \\
\hline $\mathrm{T}_{1}$ & $0.72-1.73$ & $1.65-2.50$ & $2.38-3.20$ & $4.14-6.35$ & $5.30-7.31$ & $7.22-8.45$ \\
\hline $\mathrm{T}_{2}$ & $0.68-1.78$ & $1.40-2.3$ & $1.85-2.50$ & $2.72-4.36$ & $3.89-5.14$ & $4.16-5.23$ \\
\hline $\mathrm{T}_{3}$ & $0.82-1.74$ & $1.37-2.1$ & $1.72-2.55$ & $2.68-4.11$ & $3.57-4.82$ & $3.91-4.94$ \\
\hline $\mathrm{T}_{4}$ & $0.75-1.80$ & $1.28-2.1$ & $1.56-2.27$ & $2.41-3.9$ & $3.17-4.20$ & $3.62-4.35$ \\
\hline
\end{tabular}

Table 1. Salinity levels at different growth stage of potato in the experimental plots at FSRD site Hazirhat, Noakhali $* \mathrm{~T}_{1}=$ No Mulch, $\mathrm{T}_{2}=56 \mathrm{tha}^{-1}, \mathrm{~T}_{3}=62 \mathrm{tha}^{-1}, \mathrm{~T}_{4}=62 \mathrm{tha}^{-1}$

\begin{tabular}{|l|c|c|c|c|c|c|}
\hline Treatment & \multicolumn{5}{|c|}{ Salinity range (dS m-1) } & \\
\cline { 2 - 7 } & Seedling & $\begin{array}{c}\text { Formation of } \\
\text { side shoots }\end{array}$ & $\begin{array}{c}\text { Inflorescence } \\
\text { emergence }\end{array}$ & Flowering & $\begin{array}{c}\text { Development } \\
\text { of fruit }\end{array}$ & $\begin{array}{c}\text { Ripening } \\
\text { of fruit }\end{array}$ \\
\hline $\mathrm{T}_{1}$ & $0.82-1.83$ & $1.35-2.10$ & $2.47-3.31$ & $3.14-4.65$ & $5.40-8.11$ & $7.13-9.25$ \\
\hline $\mathrm{T}_{2}$ & $0.78-1.78$ & $1.33-2.15$ & $1.91-2.61$ & $2.52-3.31$ & $3.95-5.10$ & $4.26-5.15$ \\
\hline $\mathrm{T}_{3}$ & $0.85-1.89$ & $1.38-2.19$ & $1.69-2.53$ & $2.38-3.14$ & $3.42-4.66$ & $3.71-4.64$ \\
\hline $\mathrm{T}_{4}$ & $0.89-1.97$ & $1.40-2.22$ & $1.45-2.44$ & $2.11-2.99$ & $3.13-4.00$ & $3.32-4.21$ \\
\hline
\end{tabular}

Table 2. Salinity levels at different growth stage of tomato in the experimental plots at FSRD site Hazirhat, Noakhali $* \mathrm{~T}_{1}=$ No Mulch, $\mathrm{T}_{2}=56 \mathrm{tha}^{-1}, \mathrm{~T}_{3}=62 \mathrm{tha}^{-1}, \mathrm{~T}_{4}=62 \mathrm{tha}^{-1}$

\begin{tabular}{|c|c|c|c|c|c|}
\hline Treatment & $\begin{array}{l}\text { Plant height } \\
\text { (cm) }\end{array}$ & $\begin{array}{c}\text { No. of } \\
\text { stem hill' }^{-1}\end{array}$ & $\begin{array}{l}\text { No. of tuber } \\
\text { hill }^{-1}\end{array}$ & $\begin{array}{c}\text { Tuber wt. } \\
\text { hill- }^{-1}(\mathrm{~g})\end{array}$ & $\begin{array}{l}\text { Yield } \\
\left(\mathrm{t} \mathrm{ha}^{-1}\right)\end{array}$ \\
\hline $\mathrm{T}_{1}=$ No Mulch & 34.10 & 4.11 & 5.86 & 259.4 & 18.58 \\
\hline $\mathrm{T}_{2}=56 \mathrm{t} \mathrm{ha}^{-1}$ & 40.72 & 4.67 & 6.65 & 327.3 & 22.23 \\
\hline $\mathrm{T}_{3}=62 \mathrm{tha}^{-1}$ & 43.89 & 4.88 & 7.05 & 369.7 & 24.13 \\
\hline $\mathrm{T}_{4}=68 \mathrm{t} \mathrm{ha}^{-1}$ & 45.67 & 5.04 & 7.87 & 406.1 & 26.46 \\
\hline LSD (0.05) & 5.103 & NS & 0.27 & 13.44 & 1.62 \\
\hline CV $(\%)$ & 8.03 & 4.47 & 2.26 & 7.49 & 8.15 \\
\hline
\end{tabular}

Table 3. Effect of different amount of water hyacinth as mulch on the yield and yield contributing characters of Potato (Pooled 2014-15 and 2015-16)

\begin{tabular}{|c|c|c|c|c|}
\hline Treatment & $\begin{array}{l}\text { Plant height } \\
(\mathbf{c m})\end{array}$ & $\begin{array}{l}\text { No. of fruits } \\
\text { plant }^{-1}\end{array}$ & $\begin{array}{l}\text { Individual } \\
\text { fruit wt. (g) }\end{array}$ & $\begin{array}{c}\text { Yield } \\
\left(\mathrm{t} \mathrm{ha}^{-1}\right)\end{array}$ \\
\hline $\mathrm{T}_{1}=$ No Mulch & 103.68 & 21.10 & 73.39 & 55.13 \\
\hline $\mathrm{T}_{2}=56 \mathrm{t} \mathrm{ha}^{-1}$ & 108.05 & 24.63 & 75.06 & 62.72 \\
\hline$T_{3}=62 \mathrm{tha}^{-1}$ & 108.93 & 26.72 & 75.97 & 65.85 \\
\hline $\mathrm{T}_{4}=68 \mathrm{tha}^{-1}$ & 109.41 & 28.15 & 76.14 & 67.29 \\
\hline LSD (0.05) & NS & 1.59 & NS & 7.70 \\
\hline CV (\%) & 7.82 & 6.20 & 3.89 & 8.27 \\
\hline
\end{tabular}

Table 4. Effect of different amount of water hyacinth as mulch on the yield and yield contributing characters of Tomato (Pooled 2014-15 and 2015-16)

\begin{tabular}{|c|c|c|c|c|}
\hline Treatment & $\begin{array}{l}\text { Yield } \\
\left(\mathrm{t} \mathrm{ha}^{-1}\right)\end{array}$ & $\begin{array}{l}\text { Gross return } \\
\left(\text { Tk. }^{-1} \mathrm{ha}^{-1}\right)\end{array}$ & $\begin{array}{l}\text { Total Variable } \\
\text { Cost } \\
\left(\text { Tk. ha }^{-1}\right)\end{array}$ & $\begin{array}{l}\text { Gross Margin } \\
\left(\mathrm{Tk}^{\left.-h^{-1}\right)}\right.\end{array}$ \\
\hline $\mathrm{T}_{1}=$ No Mulch & 18.58 & 185800 & 85700 & 100100 \\
\hline $\mathrm{T}_{2}=56 \mathrm{tha}^{-1}$ & 22.23 & 222300 & 93400 & 128900 \\
\hline $\mathrm{T}_{3}=62 \mathrm{tha}^{-1}$ & 24.13 & 241300 & 96700 & 144600 \\
\hline $\mathrm{T}_{4}=68 \mathrm{tha}^{-1}$ & 26.46 & 264600 & 98800 & 165800 \\
\hline
\end{tabular}

Table 5. Cost and return analysis of potato as influenced by different amount of water hyacinth as mulch at FSRD site, Hazirhat, Noakhali

*Note: Potato @ 10 Tk. kg-1 


\begin{tabular}{|l|c|l|c|c|}
\hline Treatment & $\begin{array}{c}\text { Yield } \\
\left(\mathrm{t} \mathrm{ha}^{-1}\right)\end{array}$ & $\begin{array}{l}\text { Gross return } \\
\left(\mathrm{Tk} . \mathrm{ha}^{-1}\right)\end{array}$ & $\begin{array}{c}\text { Total Variable } \\
\text { Cost }\left(\mathrm{Tk} . \mathrm{ha}^{-1}\right)\end{array}$ & $\begin{array}{c}\text { Gross Margin } \\
\left(\mathrm{Tk} . \mathrm{ha}^{-1}\right)\end{array}$ \\
\hline $\mathrm{T}_{1}=$ No Mulch & 55.13 & 661560 & 138750 & 522810 \\
\hline $\mathrm{T}_{2}=56 \mathrm{tha}^{-1}$ & 62.72 & 752640 & 154250 & 598390 \\
\hline $\mathrm{T}_{3}=62 \mathrm{tha}^{-1}$ & 65.85 & 790200 & 157400 & 632800 \\
\hline $\mathrm{T}_{4}=68 \mathrm{tha}^{-1}$ & 67.29 & 807480 & 160550 & 646930 \\
\hline
\end{tabular}

Table 6. Cost and return analysis of tomato as influenced by different amount of water hyacinth as mulch at FSRD site, Hazirhat, Noakhali

*Note: Tomato @ $12 \mathrm{Tk} . \mathrm{kg}^{-1}$

\section{References}

Allamanas, R.E.A., Halaure, W., Nelson, W. and Evans, S.D. (1977) Surface energy balance and soil thermal property modifications by tillage induced soil structure. Tech. Bull 306. University of Minnesota, USA, p 12.

Anonymous. 2001. BARI Annual Report 1999-2000. p242.

BBS (Bangladesh Bureau of Statistics) (2014) The Year Book of Agricultural Statistics of Bangladesh. Stat. Div. Minis. Planning, Govt. Peoples Repub. Bangladesh, Dhaka.

Chi, B., Pang, J., Jiao, X., (1994) Effects of Residue Mulch Methods in Control of Salinization in Root Zone. J. Shanxi Agric. Univ. 14, 440-443.

Choudhury, M. R. and Prihar, S.S. (1974) Root development and growth response of corn following mulching cultivation and inter row compaction. Agron. J. 66: 350-355.

FAO. 2001. Land Resources Appraisal of Bangladesh for Agricultural Development Report 2, Food and Agricultural Organization, UNDP, Rome, p 341.

Islam, M.Z., Zaman M.M., Hossain M.M., Hossain, A. (2009) Intregated nutrient management with liming for potato production in North-West region of Bangladesh. Annual Report 2008-2009, Tuber Crops Research Centre, Bangladesh Agricultural Res. Inst., Gazipur, Bangladesh

Jalil, M.A., Azad M.A.K., Farooque A.M. (2004) Effect of Different Mulches on the growth and Yield of Two Potato Varieties. J. Bio.Sciences 4(3): 331-333.

Karim, Z., Hussain, S.G. and Ahmed, M. (1990) Salinity Problems and Crop Intensification in the Coastal Region of Bangladesh, p14.

Kayum, M.A., Asaduzzaman, M., Haque, M.Z. (2008) Effects of Indigenous Mulches on Growth and Yield of Tomato. J. Agric. Rural Dev. 6(1\&2),1-6.

Razzaque, M.A., Ali, M.A.(2009) Effect of Mulching Materials on the Yield and Quality of Potato Varieties under no Tillage Condition of Ganges Tidal Flood Plain Soil. Bangladesh J. Sci. Ind. Res. 44(1), 51-56.

Rahaman, M. J., M. S. Uddin, M. J. Uddin, S. A. Bagum, N. K. Halder and M. F. Hossain. (2004) Effect of mulches on potato at saline soil of southern Bangladesh. J. of Bio. Sciences. 4 (1): 1-4

S.K. Rautaray (2010) Benefits of mulching with dried water hyacinth or paddy straw. Potato J. 37 (1 - 2): 32-36 